\title{
Hess Opinions: An interdisciplinary research agenda to explore the unintended consequences of structural flood protection
}

\author{
Giuliano Di Baldassarre ${ }^{1,2}$, Heidi Kreibich ${ }^{3}$, Sergiy Vorogushyn ${ }^{3}$, Jeroen Aerts ${ }^{4}$, Karsten Arnbjerg-Nielsen ${ }^{5}$, \\ Marlies Barendrecht $^{6}$, Paul Bates ${ }^{7}$, Marco Borga ${ }^{8}$, Wouter Botzen ${ }^{4,9}$, Philip Bubeck ${ }^{10}$, Bruna De Marchi ${ }^{11}$, \\ Carmen Llasat $^{12}$, Maurizio Mazzoleni ${ }^{13}$, Daniela Molinari ${ }^{14}$, Elena Mondino ${ }^{1,2}$, Johanna Mård ${ }^{1,2}$, Olga Petrucci ${ }^{15}$, \\ Anna Scolobig ${ }^{16}$, Alberto Viglione ${ }^{17}$, and Philip J. Ward ${ }^{4}$ \\ ${ }^{1}$ Department of Earth Sciences, Uppsala University, Uppsala, 75236, Sweden \\ ${ }^{2}$ Centre of Natural Hazards and Disaster Science (CNDS), Sweden \\ ${ }^{3}$ GFZ German Research Centre for Geosciences, 14473 Potsdam, Germany \\ ${ }^{4}$ Institute for Environmental Studies, Vrije Universiteit Amsterdam, Amsterdam, 1081, the Netherlands \\ ${ }^{5}$ Department of Environmental Engineering, Technical University of Denmark, Kgs. Lyngby, 2800, Denmark \\ ${ }^{6}$ Centre for Water Resource Systems, Vienna University of Technology, 1040 Vienna, Austria \\ ${ }^{7}$ School of Geographical Sciences, University of Bristol, Bristol, BS8 1SS, UK \\ ${ }^{8}$ Department of Land, Environment, Agriculture and Forestry, Università degli Studi di Padova, Padova, 35122, Italy \\ ${ }^{9}$ Utrecht University School of Economics (USE.), Utrecht University, Utrecht, the Netherlands \\ ${ }^{10}$ Institute of Earth and Environmental Science, University of Potsdam, 14469 Potsdam, Germany \\ ${ }^{11}$ SVT, Centre for the Study of the Sciences and the Humanities, University of Bergen, Bergen, 5020, Norway \\ ${ }^{12}$ Department of Applied Physics, University of Barcelona, Barcelona, 08007, Spain \\ ${ }^{13}$ Department of Integrated Water Systems and Governance, IHE Delft, Delft, 2601, the Netherlands \\ ${ }^{14}$ Department of Civil and Environmental Engineering, Politecnico di Milano, Milan, 20133, Italy \\ ${ }^{15}$ CNR-IRPI National Research Council - Research Institute for Geo-Hydrological Protection, Rende (CS), 87036, Italy \\ ${ }^{16}$ Department of Environmental Systems Science, ETH Zürich, Zürich, 8092, Switzerland \\ ${ }^{17}$ Centre for Water Resource Systems, Vienna University of Technology, 1040 Vienna, Austria
}

Correspondence: Giuliano Di Baldassarre (giuliano.dibaldassarre@geo.uu.se)

Received: 15 June 2018 - Discussion started: 16 July 2018

Revised: 10 October 2018 - Accepted: 23 October 2018 - Published: 30 October 2018

\begin{abstract}
One common approach to cope with floods is the implementation of structural flood protection measures, such as levees or flood-control reservoirs, which substantially reduce the probability of flooding at the time of implementation. Numerous scholars have problematized this approach. They have shown that increasing the levels of flood protection can attract more settlements and high-value assets in the areas protected by the new measures. Other studies have explored how structural measures can generate a sense of complacency, which can act to reduce preparedness. These paradoxical risk changes have been described as "levee effect", "safe development paradox" or "safety dilemma". In this commentary, we briefly review this phenomenon by critically analysing the intended benefits and unintended effects
\end{abstract}

of structural flood protection, and then we propose an interdisciplinary research agenda to uncover these paradoxical dynamics of risk.

\section{Premise}

Economic losses caused by floods are increasing in many regions of the world, and flood risk will likely further increase because of climatic and socio-economic changes (Aerts et al., 2014; Alfieri et al., 2016). One common approach to cope with floods is the implementation of structural flood protection measures, such as levees or flood-control reservoirs. These types of infrastructure have been implemented 
for many centuries in different areas around the world, as they can significantly reduce the probability of flooding. In the Netherlands, for example, the current levee system is able to withstand floods up to return periods ranging from 500 to 10000 years (De Moel et al., 2011). In many parts of Europe, USA and Australia, flood protection measures are typically designed to protect people and assets from events with return periods between 100 and 1000 years (Bubeck et al. 2017). Conversely, most low-income countries currently have lower protection standards (Scussolini et al., 2016), and flooding events are therefore more frequent.

Recently, a global study of flood risk in a changing climate (Ward et al., 2017) has shown that the expected benefits of structural protection measures preventing frequent flooding often outweigh their building costs. This study made the (common) assumption that future flood exposure depends on socio-economic trends only, and not on the level of flood protection. However, since the studies of Gilbert White on human adjustments to floods (White, 1945), numerous scholars (White, 1994; Tobin, 1995; Burby, 2006; Kates et al., 2006; Burton and Cutter, 2008; Montz and Tobin, 2008; Scolobig and De Marchi, 2009; Ludy and Kondolf, 2012; Di Baldassarre et al., 2013a, b; 2015; Wenger, 2015) have shown that increasing levels of flood protection can also be associated with unexpected increases in flood exposure. Figure 1 depicts how the urbanization of flood-prone areas (and therefore flood exposure) can be influenced by structural flood protection. Figure 1a and b start from the same historical settlement (i.e. the orange buildings) and then show the urbanization of flood-prone areas. If such an urbanization was triggered by socio-economic trends only (e.g. population growth), the spatial distribution of the new settlements would be the same. However, the presence of structural flood protection tends to create incentives to build closer to the river and therefore increases flood exposure (compare Fig. 1a and b). Thus, socioeconomic trends determine the amount of urbanization increase, while the presence of structural flood protection influences the spatial location of new settlements and as such may lead to increased flood exposure. This tendency is typically described as the "levee effect", although some scholars have used different terms, such as "safe development paradox" or "safety dilemma" (Burby, 2006; Scolobig and De Marchi, 2009). This phenomenon can offset part of the intended benefits of structural flood protection and, paradoxically, flood risk can even increase in the medium-long term after the introduction or reinforcement of a structural flood protection (Kates et al., 2006; Montz and Tobin, 2008; Di Baldassarre et al., 2013b).

\section{The troubles with structural flood protection}

\subsection{Increasing exposure}

The aforementioned studies have discussed how building levees (or other types of structural protection measures, such as flood-control reservoirs) is often associated with more intense urbanization of flood-prone areas behind the levee (Fig. 1); i.e. more people and assets will eventually be exposed to less frequent but potentially catastrophic flooding (White, 1994; Tobin, 1995; Burby, 2006; Kates et al., 2006; Burton and Cutter, 2008; Montz and Tobin, 2008; Scolobig and De Marchi, 2009; Ludy and Kondolf, 2012; Di Baldassarre et al., 2013a, b; 2015; Wenger, 2015). This phenomenon has been observed in many parts of the world, including Bangladesh (Ferdous et al., 2018) in Asia, the Netherlands (De Moel et al., 2011), Central Pyrenees (Benito et al., 1998) and the Po River valley (Di Baldassarre et al., 2013b) in Europe, Brisbane (Bohensky and Leitch, 2014) in Australia, and the Sacramento Valley (Ludy and Kondolf, 2012) and New Orleans (Kates et al., 2006; Colten and De Marchi, 2009) in the United States.

De Moel et al. (2011), for example, analysed changes in flood exposure in the Netherlands by using land-use data with information about the maximum flood inundation. The study showed that the urban area that can be potentially flooded has increased six-fold during the 20th century. Moreover, it showed that while the proportion of urban areas in flood-prone areas substantially dropped after the occurrence of a catastrophic flooding in 1953, this proportion has started to grow again over recent decades (from about $27 \%$ to about $31 \%$ ), as flood protection was increased by introducing numerous structural measures, such as the Delta Works. This growth has brought economic benefits to these areas, but also offset part of the decline in flood risk that resulted from the strengthening of flood protection.

It should be mentioned that urban growth behind the dikes is often factored into the risk analysis. A recent study (Hallegatte, 2017) finds that whilst structural protection measures can increase potential losses (especially of large events) due to increased exposure, it can also generate benefits through more investment and economic activity. Indeed, this is one of the goals of flood protection investments: not only to reduce flood risk, but also to make it possible to facilitate economic growth in areas that are flood-prone but valuable, e.g. coastal areas that offer low trade and transport costs or areas in cities that benefit from the proximity of jobs and services (Hallegatte, 2017). However, in other cases, urban growth in flood-prone areas goes beyond original plans, as depicted for example in Fig. 1, potentially leading to unforeseen increases in flood risk. Whether this happens does not depend on the level of protection, but on risk communication and the specific societal and political context. In recent decades, it has been increasingly recognized in many countries that a residual risk of flooding remains behind levees (Bubeck et al. 

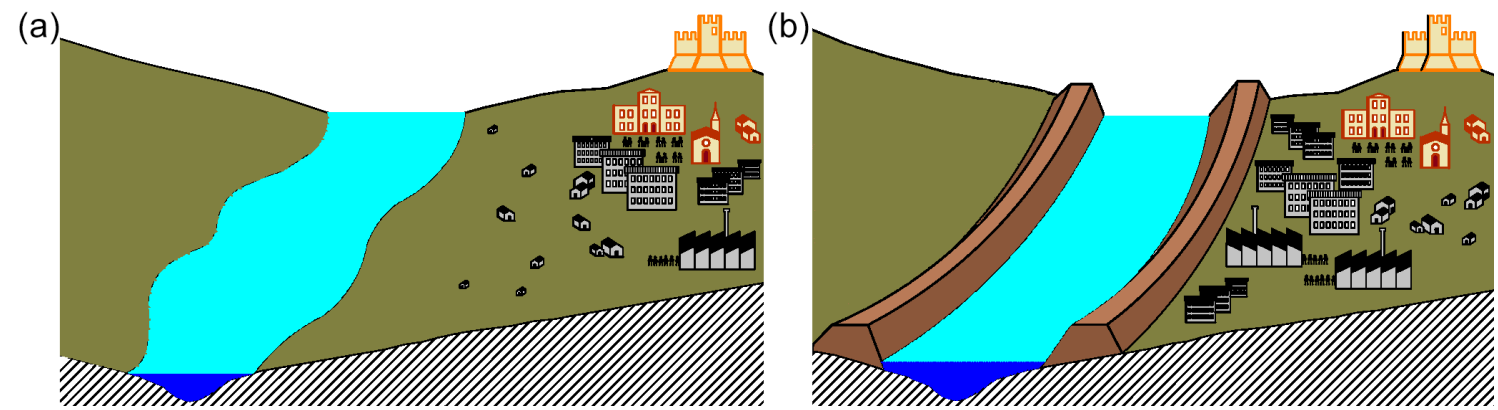

Figure 1. Hypothetical urbanization patterns without (a) and with (b) levees. The presence of levees often triggers more intense urbanization (in grey) in flood-prone areas, which can offset (at least part of) the initial benefits of flood protection.

2017; Penning-Rowsell et al., 2006). However, in other contexts, structural flood protection is still commonly accompanied by the belief that protected areas are safe and flood problems are solved by means of engineering. In these cases, levees often fuel growing flood exposure, thereby increasing flood risk. This can imply that, based on cost-benefit analysis (Kind, 2014), it becomes economically beneficial to strengthen flood protection again (see next Sect. 2.2). Thus, the overall impacts of the levee effect on urban growth and flood risk depend on the specific context in which levees are planned and designed.

\subsection{Vicious cycles, lock-in conditions and unexpected failures}

The levee effect can lead to self-reinforcing feedbacks: increasing protection levels favours intense urbanization of floodplains that will then plausibly require even higher protection standards, as seen for example in the Netherlands (Di Baldassarre et al., 2015). Thus, it can generate lock-in conditions leading to exceptionally high levels of flood protection and extremely urbanized floodplains. This lock-in condition can be unsustainable (e.g. the maintenance of large infrastructure requires commitment of regular resources) or undesirable (e.g. large infrastructure can contribute to unfair distributions of risk; Masozera et al., 2007; Di Baldassarre et al., 2013b; Ferdous et al., 2018). Indeed, the costs and benefits of flood protection measures, as well as potential flood losses, are often not fairly shared across social groups (Kind et al., 2017), as seen in the aftermath of the catastrophic 2005 flooding of New Orleans (Kates et al., 2006).

Moreover, changes in technical flood protection inevitably cause spatial risk redistribution due to hydraulic interactions, e.g. risk shifts downstream due to increased levee heights upstream, but to date these effects remain poorly understood (Vorogushyn et al., 2018). Similarly, there are reports of "levee wars", i.e. where local districts (or land owners) build higher levees to prevent local flooding and make other areas riskier (e.g. Allan James and Singer, 2008).

Lastly, the shift from frequent to rare-but-catastrophic flooding generated by structural flood protection causes se- rious problems for decision-making in flood risk management, due to high uncertainty associated with the estimation of low-probability flood events, such as the 1-in-100year flood (Merz and Thieken, 2005). Additionally, rare-butcatastrophic events bear the potential of unexpected negative consequences, as they can take society by surprise and lead to a complex web of socio-economic interactions (Di Baldassarre et al., 2016), perhaps beyond the recovery potential (Merz et al., 2015).

\subsection{Increasing vulnerabilities}

Increasing the levels of flood protection can also generate a sense of complacency among the protected people, which can reduce preparedness, thereby increasing vulnerability (Tobin, 1995). This additional facet of the levee effect was explored by Scolobig and De Marchi (2009) and De Marchi and Scolobig (2011) with reference to four communities in northeastern Italy. Interviews, focus group discussions and surveys in these areas showed that residents of communities exposed to flood risk tend to underestimate, minimize or even neglect risk (see also the report in De Marchi et al., 2007). These studies showed that an important component of such an attitude is the false sense of security induced by the presence of (often impressive) structural works designed to limit risk and prevent damage. Apparently, the symbolic messages encrypted in stones ("no problem") are more powerful than the verbal messages conveyed in information campaigns ("you are protected, but not totally safe"). More specifically, De Marchi et al. (2007) report the level of agreement of the informed respondents with four statements about protection works gauged on a Likert scale from 1 to 5 (a response of 1 signifies strong disagreement with the statement, while a response of 5 indicates strong agreement). The statements are listed here from highest to lowest mean values:

- The protection works give a feeling of safety to the people living in the village (4.49).

- The protection works eliminate the possibility of serious damage (3.92). 
- The protection works promote/help the economic development of the community (3.48).

- The protection works are too expensive compared to the expected benefits (1.76).

The high mean value (4.49 out of 5) relating to the first statement suggests that structural protection plays a role in inducing a feeling of safety among residents in these risky areas. Moreover, the high agreement (3.92) with the item "elimination of serious damage" indicated that there was very little awareness of residual risk. Thus, in this area, people protected by levees were not well motivated to undertake private precautionary measures and as such are more vulnerable towards flooding, as also found in Ludy and Kondolf (2012) in the Sacramento valley.

Yet, the reality is much more complex, as multiple factors drive risk perception and the adoption of protection measures. This leads to dissimilar outcomes in different contexts. For example, Botzen et al. (2009) found that people in the Netherlands are mostly unaware of the protection level of the levees, even though such a protection level is extremely high. Moreover, recent studies in Germany (Bubeck et al., 2013) and France (Poussin et al., 2014) have found that households living in protected areas can in fact take even more risk mitigation measures, or they are more likely to have flood insurance (Bubeck et al., 2013), than the ones in unprotected areas. The latter effect is caused by the set-up of the German insurance system, which highlights the importance of contextual factors on the levee effect.

\section{Lack of knowledge}

While the levee effect has been described by many authors in different parts of the world, these studies are fragmented and have used completely different methods, hampering comparative analyses. Moreover, while some scholars have focused on the evaluation of increasing exposure, such as the intense urbanization of flood-prone areas, very few studies have focused on increased vulnerability, such as the false sense of security caused by the presence of levees. Thus, it is still unclear what the social, technical and hydrological conditions are that can (or cannot) trigger the emergence of the levee effect and to what extent. Owing to this major lack of fundamental knowledge, these effects are typically neglected in flood risk studies. This can introduce a systematic bias in the selection or prioritization of alternative strategies for flood risk reduction, for example by favouring structural measures over non-structural options likes early warning systems (Pappenberger et al., 2015, precautionary measures (Kreibich et al., 2015) and relocation (Alfieri et al., 2016).

\section{Research agenda}

Hence, we call upon hydrologists, social scientists, economists, policy makers, and flood risk experts and managers to work together, and fill this gap in knowledge on the side effects of structural flood protection measures, which hinders the development of robust and sustainable strategies to reduce the negative impacts of floods. New empirical research is needed to reveal the social, technical and hydrological factors producing the levee effect and distinguish between intended and unintended effects of structural flood protection. Our suggestion for a research agenda comprises the following three components: (1) comparative analysis of a large datasets of different case studies, (2) long-term monitoring of exposure and vulnerability dynamics, and (3) utilisation and development of new methods to explore the long-term dynamics of flood risk changes and unravel the primary mechanism generating levee effects.

\subsection{Comparative analysis}

Empirical research commonly relies on specific case studies, which are unique and have their own characteristics and processes. This can make it challenging to draw general, transferable conclusions. An approach to tackle this challenge is a comparative analysis (Kreibich et al., 2017) with the aim of finding general patterns in a large set of diverse case studies in different contexts. For instance, to support universal parameter estimation for hydrological models the Model Parameter Estimation Experiment (MOPEX) assembled and analysed a large number of datasets for a wide range of river basins throughout the world (Wagener et al., 2006). To better understand the unintended consequences of structural flood protection, there is also a need for comparative analysis of the evolution of urban planning and risk assessment policies, legislation and practices - including issues such as the decision-making processes to define building constraints in risky areas, institutional communication strategies, or the relationship between scientific and policy innovation in risk assessment. The socio-hydrological framework (Sivapalan et al., 2012), and its specific application to disaster risk reduction (Di Baldassarre et al., 2018), can provide guidance about the set of key variables to perform such a comparative analysis of the levee effect.

Hence, we suggest using case studies to identify and analyse potential or actual occurrences of the levee effect across different hydrological, technical, social and cultural settings and identify common patterns and factors that produce (or not) levee effects. Some examples of potential case studies across different contexts are provided in Table 1. 
Table 1. Monitoring levee effects over time - data needs for an empirical analysis of the levee effect and their availability in different hotspots across decades.

\begin{tabular}{|c|c|c|c|}
\hline & & \multicolumn{2}{|c|}{ Data needs } \\
\hline (Ideal case & Time series of floods & Change in flood protection standards & Change in flood exposure \\
\hline $\begin{array}{l}\text { study should be } \\
\text { available for the } \\
\text { same time pe- } \\
\text { riod over } \\
\text { several decades) }\end{array}$ & $\begin{array}{l}\text { Flood information, e.g. } \\
\text { annual maximum flows } \\
\text { or peaks over a thresh- } \\
\text { old. }\end{array}$ & $\begin{array}{l}\text { Data, indicators and proxies, e.g. build- } \\
\text { ing } \\
\text { times and heights of levees (with } \\
\text { some reasonable resolution, e.g. } 10- \\
30 \text { years). }\end{array}$ & $\begin{array}{l}\text { Data, indicators and proxies, e.g. spatio } \\
\text { temporal changes in population density, as } \\
\text { set values, land use in protected flood plain } \\
\text { (with some reasonable resolution e.g. } 10 \\
30 \text { years). }\end{array}$ \\
\hline
\end{tabular}

Change in flood vulnerability

Data, indicators or proxies, e.g. risk awareness and preparedness studies (with a focus on levee effect), emergency management (e.g. early warning times), insurance cover, evolution of regulatory frameworks, legislation, policies, decision-making processes, and communication strategies for hazard and risk assessment.

\begin{tabular}{lll}
\hline $\begin{array}{l}\text { Dresden, } \\
\text { Germany }\end{array}$ & $\begin{array}{l}\text { Annual maximum river } \\
\text { flows. }\end{array}$ & Available. \\
& & \\
\hline $\begin{array}{l}\text { Cologne, } \\
\text { Germany }\end{array}$ & $\begin{array}{l}\text { Annual maximum river } \\
\text { flows. }\end{array}$ & Availab \\
& &
\end{tabular}

Actual data availability

until 2020 for $80+$ districts of Cologne.

\section{Land-use reconstruction from 1790-2009 Estimate of asset value of residential build ings since 2000 \\ Survey data in Dresden: \\ 2002: 300 households 2005/2006: 21 households 2013: 117 households}

Development of the population since 1993
Survey data from 2012 on risk perception and perceptions towards flood risk management. Can be compared to other areas that have a much higher flood risk compared with Cologne.

$\begin{array}{lll}\begin{array}{l}\text { Northeastern } \\ \text { Italy }\end{array} & \begin{array}{l}\text { Annual maximum river } \\ \text { flows. }\end{array} & \begin{array}{l}\text { Qualitative information available in the } \\ \text { technical municipal and provincial of- } \\ \text { fices }\end{array}\end{array}$
fices.

Data available on (i) land-use change (municipal urban plans) and construction of protection works, (ii) changes in social vulnerability and population density at municipa level years (Official National Census data, conducted every 10 years since 1900 ).

Risk awareness and preparedness surveys conducted in $2005(N=400$ Trento area; $N=176$ Bolzano/Bozen area; $N=100$ Malborghetto Valbruna).

Emergency plans and flood risk maps available.

\begin{tabular}{|c|c|c|c|c|}
\hline The Netherlands & $\begin{array}{l}\text { Annual maximum river } \\
\text { flows. }\end{array}$ & Available. & Census data and land-use maps. & Risk awareness surveys in 2008. \\
\hline $\begin{array}{l}\text { Sacramento, } \\
\text { USA }\end{array}$ & $\begin{array}{l}\text { Annual maximum river } \\
\text { flows. }\end{array}$ & Available. & Census data and land-use maps. & Risk awareness surveys in 2010. \\
\hline $\begin{array}{l}\text { Jamuna River } \\
\text { floodplain in } \\
\text { Bangladesh }\end{array}$ & $\begin{array}{l}\text { Annual maximum river } \\
\text { flows. } \\
\text { Flood extent maps. }\end{array}$ & Available. & Census data and land-use maps. & Risk awareness surveys in 2017 \\
\hline Denmark & $\begin{array}{l}\text { Levees are for sea } \\
\text { surges. Detailed time } \\
\text { series, } 10 \text { series longer } \\
\text { than } 100 \text { years. }\end{array}$ & $\begin{array}{l}\text { Large flood in } 1872 \text { led to construction } \\
\text { of large dike to protect valuable farm- } \\
\text { land. No larger change in standards } \\
\text { since then. }\end{array}$ & $\begin{array}{l}\text { National compensation scheme in place since } \\
\text { 1980s. }\end{array}$ & $\begin{array}{l}\text { Land-use change and change of human } \\
\text { preference imply that levees are pro- } \\
\text { tecting the wrong locations. }\end{array}$ \\
\hline Vienna, Austria & Time series of floods. & $\begin{array}{l}\text { Reports about the various projects that } \\
\text { were undertaken throughout the years } \\
\text { to update the flood protection system of } \\
\text { Vienna. }\end{array}$ & Available. & No data available. \\
\hline $\begin{array}{l}\text { Calabria region, } \\
\text { Italy }\end{array}$ & $\begin{array}{l}\text { Time series of flood } \\
\text { levels. } \\
\text { Discharge data are not } \\
\text { available: we deal with } \\
\text { typically Mediterranean } \\
\text { ungauged torrential } \\
\text { streams. The series of } \\
\text { maximum rainfall events } \\
\text { can be used as a proxy of } \\
\text { river discharge. } \\
\text { Historical series of } \\
\text { elements damaged by } \\
\text { floods throughout the } \\
\text { time series }\end{array}$ & $\begin{array}{l}\text { Qualitative information that can be ob- } \\
\text { tained from the comparative analy- } \\
\text { sis of the different types of structural } \\
\text { works realized during the period } 1820- \\
\text { present. }\end{array}$ & $\begin{array}{l}\text { Temporal series of realization of protection } \\
\text { works (levees, check dams and other types) } \\
\text { and major land transformation since } 1850 \text {. } \\
\text { Number of inhabitants obtained from Official } \\
\text { National census: every } 10 \text { years since } 1900 \text {. } \\
\text { Map of urbanized sectors in two or three time } \\
\text { periods, depending on the availability of air } \\
\text { photos. }\end{array}$ & $\begin{array}{l}\text { Flood risk maps of PAI (Piano di As- } \\
\text { setto Idrogeologico): these maps, real- } \\
\text { ized in } 2000 \text {, classify territory accord- } \\
\text { ing to four different flood risk levels. } \\
\text { Official flood risk maps of PAI: up- } \\
\text { dated version } 2016 \text {. }\end{array}$ \\
\hline Lodi, Italy & $\begin{array}{l}\text { Annual maximum river } \\
\text { flows. } \\
\text { Annual maximum pre- } \\
\text { cipitation. }\end{array}$ & $\begin{array}{l}\text { Executive projects of the levee system } \\
\text { built after the } 2002 \text { flood with infor- } \\
\text { mation about height, material, design } \\
\text { safety level, costs and path. }\end{array}$ & $\begin{array}{l}\text { Urbanization patterns (i.e. buildings con- } \\
\text { struction time) since } 1920 \text {. } \\
\text { Number of inhabitants from official national } \\
\text { census every year since } 1900 \text {. } \\
\text { Orthoimages since } 1950 \text {. }\end{array}$ & $\begin{array}{l}\text { Risk awareness and preparedness sur- } \\
\text { vey of people affected in } 2002 \text { and still } \\
\text { living in the area ( } 10 \text { households ongo- } \\
\text { ing). } \\
\text { Emergency plans and flood risk maps } \\
\text { available. }\end{array}$ \\
\hline
\end{tabular}


Table 2. Summary of the research agenda in terms of questions, methods and outcomes.

\begin{tabular}{lll}
\hline Research question & Methods & Potential outcomes \\
\hline $\begin{array}{l}\text { Which socio-hydrological factors en- } \\
\text { hance or alleviate the levee effect? }\end{array}$ & $\begin{array}{l}\text { Comparative analysis } \\
\text { (Sect. 4.1) }\end{array}$ & $\begin{array}{l}\text { These factors would enable the identifications of contexts in } \\
\text { which increasing structural protection levels can be less ben- } \\
\text { eficial than expected. Hence, it will contribute to a better de- } \\
\text { velopment of risk reduction policies. }\end{array}$ \\
\hline $\begin{array}{l}\text { How does structural flood protection in- } \\
\text { fluence changes in risk perception and } \\
\text { flood preparedness decisions? }\end{array}$ & $\begin{array}{l}\text { Longitudinal surveys } \\
\text { (Sect. 4.2) }\end{array}$ & $\begin{array}{l}\text { Understanding what influences changes in risk perception and } \\
\text { flood preparedness decisions would suggest how to improve } \\
\text { risk awareness campaigns, thus alleviating the levee effect. }\end{array}$ \\
\hline $\begin{array}{l}\text { How does structural flood protection in- } \\
\text { fluence changes in human settlements? }\end{array}$ & $\begin{array}{l}\text { Long-term monitoring } \\
\text { (Sect. 4.2) }\end{array}$ & $\begin{array}{l}\text { Understanding how flood protection shapes human settle- } \\
\text { ments would support a more realistic assessment of long-term } \\
\text { (decadal) changes in flood exposure. }\end{array}$ \\
\hline $\begin{array}{l}\text { How does flood risk changes over time in } \\
\text { differ contexts, e.g. with or without struc- } \\
\text { tural flood protection? }\end{array}$ & $\begin{array}{l}\text { System dynamic mod- } \\
\text { elling, agent-based mod- } \\
\text { elling and new datasets } \\
\text { (Sect. 4.3) }\end{array}$ & $\begin{array}{l}\text { Modelling or observing behavioural responses would support } \\
\text { a more realistic assessment of long-term changes in flood risk } \\
\text { in different contexts. }\end{array}$ \\
\hline
\end{tabular}

\subsection{Long-term monitoring of exposure and vulnerability dynamics}

Currently, the analysis of the levee effect is largely hampered by the absence of reliable long-term information on exposure and vulnerability in the focus areas. The monitoring of spatial and temporal dynamics in vulnerability is still largely missing, and strongly limited to locations that have recently experienced catastrophic flooding. Table 1 provides an overview of the types of observations needed to uncover the unfolding of levee effects, together with the actual data availability in the case studies. The table highlights that, while systematic time series of flood hazard and exposure can be more easily obtained, systematic information across decades about vulnerability is almost never available because surveys and interviews are typically performed at one point in time only, i.e. cross-sectional.

Thus, we suggest complementary empirical data collection in the case studies via longitudinal studies, where individuals, communities and decision-makers are repeatedly interviewed to assess how changes in flood protection levels influence vulnerability and urban growth over time. Moreover, ideal case studies should also allow the analysis of counterfactual cases, i.e. how would risk have developed in an area had levees not been built. Such a study can be done by comparing urban growth in two adjacent areas, one protected by a levee and one which is not.

\subsection{Exploitation of new models, concepts and data}

We can draw from new approaches that have been developed for the study of socio-nature interactions in various interdisciplinary fields, such as ecological economics, behavioural sciences, social ecology and socio-hydrology (Folke et al., 2005; Sivapalan et al., 2012; Montanari et al., 2013; Di Bal- dassarre et al., 2013a; Aerts et al., 2018). In particular, new opportunities to simulate behavioural responses to changing flood risk and flood risk management policies are offered nowadays by system dynamics (Di Baldassarre et al., 2013a) and agent-based modelling (Werner and McNamara, 2007; Aerts et al., 2018). An example of a paper that integrates behavioural theories of decision-making under risk in hydrological modelling is the research by Haer et al. (2017). They apply the well-known expected utility theory (von Neumann and Morgenstern, 1953) of individual decision-making under risk, to simulate household flood preparedness behaviour under increasing flood risk. The same study compares this behaviour with boundedly rational behaviour, using the prospect theory developed by Kahneman and Tversky (2013). The latter captures situations in which individuals make flood adaptation decisions, while either underweighting of high-probability events or overweighting of low-probability flood events in their decision to invest in flood damage mitigation measures. Another study is by Haer et al. (2016), who apply an agent based model that includes decision rules based on protection motivation theory to show the effect of risk communication on flood adaptation decisions.

These new models can guide empirical data collection to test alternative hypotheses about the primary mechanisms that can (or cannot) generate the levee effect in different contexts. This knowledge can be complemented by participatory approaches for co-generating knowledge between experts and stakeholders (Nature, 2018) in order to identify technical and policy options to address the unintended consequences of structural flood protection. Moreover, the protection motivation theory can also help explain the mitigation behaviour of individuals, which influences the vulnerability of those living behind the levees (Bubeck et al., 2012). It is 
particularly important to focus on what motivates protection and to provide a link between protection and communication theory or theories, by clearly identifying which communication tools and contents trigger attitudinal and behavioural change, e.g. for residual risk communication. Lastly, the increasing availability of remotely sensed data and advanced information extraction methods, such as night-light data extraction (Ceola et al., 2014; Mård et al., 2018), allows analyses of exposure dynamics over longer time spans.

\section{Summary}

We posit that exploiting these different methods, concepts and data within the suggested research agenda would significantly improve our understanding of the unintended effects of flood protection. This advanced knowledge will improve our ability to assess and explain changes in flood risk. Also, it will provide more empirical evidence supporting the selection of strategies and measures for flood risk reduction. More specifically, Table 2 shows the main research questions that remain unanswered, what elements of the proposed research agenda can help address them, and how addressing these questions can contribute to better flood risk policies.

Data availability. No data sets were used in this article.

Author contributions. This commentary originates from wideranging discussions during three workshops (Leeds, UK, 2017; New Orleans, USA, 2018; Vienna, Austria, 2018) of the working group on Changes in Flood Risk within the Panta Rhei research initiative of the International Association of Hydrological Sciences (IAHS). GDB led the writing process and conceived Fig. 1. HK and SV developed the research agenda and the table of data needs and availability. All the co-authors substantially contributed to the commentary with original ideas, potential case studies or revising/editing of the text.

Competing interests. The authors declare that they have no conflict of interest.

Acknowledgements. This work was developed within the activities of the working group on Changes in Flood Risk of the Panta Rhei research initiative of the International Association of Hydrological Sciences (IAHS). Giuliano Di Baldassarre was supported by the European Research Council (ERC) within the project "HydroSocialExtremes: Uncovering the Mutual Shaping of Hydrological Extremes and Society", ERC Consolidator Grant no. 761678. Karsten Arnbjerg-Nielsen was supported by Innovation Fund Denmark through the Water Smart Cities Project, grant 51570009B. Philip Bubeck is supported by a Royal Society Wolfson Research Merit Award and a Leverhulme Research Fellowship. Philip J. Ward and Wouter Botzen received funding from the
Netherlands Organisation for Scientific Research (NWO) in the form of VIDI grants 016.161.324 and 45214005.

Edited by: Hilary McMillan

Reviewed by: two anonymous referees

\section{References}

Aerts, J. C. J. H., Botzen, W. W., Emanuel, K., Lin, N., de Moel, H., and Michel-Kerjan, E. O.: Evaluating flood resilience strategies for coastal megacities, Science, 344, 473-475, 2014.

Aerts, J. C. J. H., Botzen, W. J. W., Clarke, K. C., Cutter, S., Hall, J., Merz, B., Michel-Kerjan, E., Mysiak, J., Surminski, S., and Kunreuther, H.: Integrating human behavior dynamics into flood disaster risk assessment, Nat. Clim. Change, 8, 193-199, 2018.

Alfieri, L., Feyen, L., and Di Baldassarre, G.: Increasing flood risk under climate change: a pan-European assessment of the benefits of four adaptation strategies, Climatic Change, 136, 507-521, https://doi.org/10.1007/s10584-016-1641-1, 2016.

Allan James, L. and Singer, M. B.: Development of the lower Sacramento Valley flood-control system: Historical perspective, Nat. Hazards Rev., 9, 125-135, 2008.

Benito, G., Grodek, T., and Enzel, Y.: The geomorphic and hydrologic impacts of the catastrophic failure of flood-control-dams during the 1996-Biescas flood (Central Pyrenees, Spain), Z. Geomorphol., 42, 417-437, 1998.

Bohensky, E. and Leitch A.: Framing the flood: a media analysis of themes of resilience in the 2011 Brisbane flood, Reg. Environ. Change, 14, 475-488, https://doi.org/10.1007/s10113-013-04382, 2014.

Botzen, W. J. W., Aerts, J. C. J. H., and van den Bergh, J. C. J. M.: Dependence of flood risk perceptions onsocioeconomic and objective risk factors, Water Resour. Res., 45, W10440, https://doi.org/10.1029/2009WR007743, 2009.

Bubeck, P., Botzen, W. J., and Aerts, J. C.: A review of risk perceptions and other factors that influence flood mitigation behavior, Risk Anal., 32, 1481-1495, 2012.

Bubeck, P., Botzen, W. J. W., Kreibich, H., and Aerts, J. C. J. H.: Detailed insights into the influence of flood-coping appraisals on mitigation behaviour, Global Environmental Change, 23, 13271338, 2013.

Bubeck, P., Kreibich, H., Penning-Rowsell, E., Botzen, W. W., de Moel, H., and Klijn, F.: Explaining differences in flood management approaches in Europe and the USA - A comparative analysis, J. Flood Risk Manag., 10, 436-445, 2017.

Burby, R. J.: Hurricane Katrina and the paradoxes of government disaster policy: Bringing about wise governmental decisions for hazardous areas, Ann. Am. Acad. Polit. SS, 604, 171-191, 2006.

Burton, C. and Cutter, S. L.: Levee failures and social vulnerability in the Sacramento-San Joaquin Delta area, California, Nat. Hazards Rev., 9, 136-149, 2008.

Ceola, S., Laio, F., and Montanari, A.: Satellite nighttime lights revealing increased human exposure to floods worldwide, Geophys. Res. Lett., 41, 7184-7190, 2014.

Colten, C.: An Unnatural Metropolis: Wresting New Orleans from Nature, LSU Press, Baton Rouge, La, 2015.

Colten, C. C. and De Marchi, B.: Hurricane Katrina: The Highly Anticipated Surprise, in: Città salute e sicurezza, Strumenti di 
governo e casi di studio, edited by: Treu, M. C., Politecnica, Maggioli, Sant'Arcangelo di Romagna, 638-667, 2009.

De Marchi B. and Scolobig A.: The views of experts and residents on social vulnerability to flash floods in an Alpine region of Italy, Journal of Theoretical Social Psychology, 36, https://doi.org/10.1111/j.1467-7717.2011.01252.x, 2011.

De Marchi B., Scolobig A., Delli Zotti G., and Del Zotto M.: Risk construction and social vulnerability in an Italian Alpine Region, Country Report T11-06-12 of FLOODsite Integrated Project, European Commission 6th Framework Programme, available at: http://www.floodsite.net/html/partner_area/project docs/Task11_p33_06-08_final.pdf (last access: 22 May 2018), 344 pp., 2007.

De Moel, H., Aerts, J. C., and Koomen, E.: Development of flood exposure in the Netherlands during the 20th and 21st century, Global Environmental Change, 21, 620-627, 2011.

Di Baldassarre, G., Viglione, A., Carr, G., Kuil, L., Salinas, J. L., and Blöschl, G.: Socio-hydrology: conceptualising humanflood interactions, Hydrol. Earth Syst. Sci., 17, 3295-3303, https://doi.org/10.5194/hess-17-3295-2013, 2013 a.

Di Baldassarre, G., Kooy, M., Kemerink, J. S., and Brandimarte, L.: Towards understanding the dynamic behaviour of floodplains as human-water systems, Hydrol. Earth Syst. Sci., 17, 3235-3244, https://doi.org/10.5194/hess-17-3235-2013, 2013 b.

Di Baldassarre, G., Viglione, A., Carr, G., Kuil, L., Yan, K., Brandimarte, L., and Blöschl, G.: Debates-Perspectives on sociohydrology: Capturing feedbacks between physical and social processes, Water Resour. Res., 51, 4770-4781, 2015.

Di Baldassarre, G., Nohrstedt, D., Mård, J., Burchardt, S., Albin, C., Bondesson, S., Breinl, K., Deegan, F. M., Fuentes, D., Lopez, M. G., Granberg, M., Nyberg, L., Nyman, M. R., Rhodes, E., Troll, V., Young, S., Walch, C., and Parker, C. F.: An Integrative Research Framework to Unravel the Interplay of Natural Hazards and Vulnerabilities, Earth's Future, 6, 305-310, 2018.

Di Baldassarre, G., L. Brandimarte, and Beven K.: The seventh facet of uncertainty: wrong assumptions, unknowns and surprises in the dynamics of human-water systems, Hydrolog. Sci. J., 61, 1748-1758, 2016.

Ferdous, M. R., Wesselink, A., Brandimarte, L., Slager, K., Zwarteveen, M., and Di Baldassarre, G.: Socio-hydrological spaces in the Jamuna River floodplain in Bangladesh, Hydrol. Earth Syst. Sci., 22, 5159-5173, https://doi.org/10.5194/hess-225159-2018, 2018.

Folke, C., Hahn, T., Olsson, P., and Norberg J.: Adaptive governance of social-ecological systems, Annu. Rev. Environ. Resour., 30, 441-73, 2005.

Haer, T., Botzen, W., and Aerts, J.: The effectiveness of flood risk communication strategies and the influence of social networks: insights from an agent-based model, Environ. Sci. Policy, 60, 44 52, 2016.

Haer, T., Botzen, W., de Moel, H., and Aerts, J. C. J. H.: Integrating household risk mitigation behaviour in flood risk analysis: An agent-based model approach, Risk Anal., 37, 1977-1992, 2017.

Hallegatte, S.: A normative exploration of the link between development, economic growth, and natural risk, Economics of Disasters and Climate Change, 1, 5-31, 2017.

Kahneman, D. and Tversky, A.: 2013 Prospect theory: An analysis of decision under risk, in: Handbook of the fundamentals of financial decision making: Part I, 99-127, 2013.
Kates, R. W., Colten, C. E., Laska, S., and Leatherman, S. P.: Reconstruction of New Orleans after Hurricane Katrina: a research perspective, P. Natl. Acad. Sci. USA, 103, 14653-14660, 2006.

Kind, J., Botzen, W. J., and Aerts, J. C. J. H.: Accounting for risk aversion, income distribution and social welfare in costbenefit analysis for flood risk management, WIRES Water, https://doi.org/10.1002/wcc.446, 2017.

Kind, J. M.: Economically efficient flood protection standards for the Netherlands, J. Flood Risk Manag., 7, 103-117, 2014.

Kreibich, H., Bubeck, P., Van Vliet, M., and De Moel, H.: A review of damage-reducing measures to manage fluvial flood risks in a changing climate, Mitig. Adapt. Strat. Gl., 20, 967-989, 2015.

Kreibich, H., Di Baldassarre, G., Vorogushyn, S., Aerts, J. C. J. H., Apel, H., Aronica, G. T., Arnbjerg-Nielsen, K., Bouwer, L. M., Bubeck, P., Caloiero, T., Do, T. C., Cortès, M., Gain, A. K., Giampá, V., Kuhlicke, C., Kundzewicz, Z. W., Llasat, M. C., Mård, J., Matczak, P., Mazzoleni, M., Molinari, D., Nguyen, D., Petrucci, O., Schröter, K., Slager, K., Thieken, A. H., Ward, P. J., and Merz, B.: Adaptation to flood risk - results of international paired flood event studies, Earth's Future, 5, 10, 953-965, 2017.

Ludy, J. and Kondolf, G. M.: Flood risk perception in lands "protected" by 100-year levees, Natural Hazards, 61, 829-842, 2012.

Mård, J., Di Baldassarre, G., and Mazzoleni, M.: Nighttime light data reveal how flood protection shapes human proximity to rivers, Sci. Adv., 4, eaar5779, https://doi.org/10.1126/sciadv.aar5779, 2018.

Masozera, M., Bailey, M., and Kerchner, C.: Distribution of impacts of natural disasters across income groups: A case study of New Orleans, Ecol. Econ., 63, 299-306, 2007.

Merz, B. and Thieken, A. H.: Separating natural and epistemic uncertainty in flood frequency analysis, J. Hydrol., 309, 114-132, 2005.

Merz, B., Vorogushyn, S., Lall, U., Viglione, A., and Blöschl, G.: Charting unknown waters - On the role of surprise in flood risk assessment and management, Water Resour. Res., 51, 63996416, 2015.

Montanari, A., Young, G., Savenije, H. H. G., Hughes, D., Wagener, T., Ren, L. L., Koutsoyiannis, D., Cudennec, C., Toth, E., Grimaldi, S., Bl“schl, G., Sivapalan, M., Bevenl, K., Gupta, H., Hipsey, M., Schaefli, B., Arheimer, B., Boegh, E., Schymanski, S. J., Di Baldassarre, G., Yu, B., Hubert, P., Huang, Y., Schumann, A., Post, D., Srinivasan, V., Harman, C., Thompson, S., Rogger, M., Viglione, A., McMillan, H., Characklis, G., Pang, Z., and Belyaev, V.: Panta Rhei - Everything Flows: Change in hydrology and society - The IAHS Scientific Decade 2013-2022, Hydrolog. Sci. J., 58, 1256-1275, https://doi.org/10.1080/02626667.2013.809088, 2013.

Montz, B. E. and Tobin, G. A.: Livin'large with levees: Lessons learned and lost, Nat. Hazards Rev., 9, 150-157, 2008.

Nature (Editorial): The best research is produced when researchers and communities work together, Nature, 562, https://doi.org/10.1038/d41586-018-06855-7, 2018.

Pappenberger, F., Cloke, H. L., Parker, D. J., Wetterhall, F., Richardson, D. S., and Thielen, J.: The monetary benefit of early flood warnings in Europe, Environ. Sci. Policy, 51, 278-291, 2015.

Penning-Rowsell E., Johnson C., and Tunstall S.: "Signals" from pre-crisis discourse: lessons from UK flooding for global environmental policy change?, Glob. Environ. Change, 16, 323-339, 2006. 
Poussin, J., Botzen, W. J. W., and Aerts, J. C. J. H.: Factors of influence on flood damage mitigation behaviour by households Literature review and results from a French survey, Environ. Sci. Policy, 40, 69-77, 2014.

Scolobig, A. and De Marchi, B.: Dilemmas in land use planning in flood prone areas, in: Flood Risk Management: Research and Practice, edited by: Samuels, P., Huntington, S., Allsop, W., and Harrop, J., Taylor and Francis Group, London, ISBN: 978-0-41548507-4, 2009.

Scussolini, P., Aerts, J. C. J. H., Jongman, B., Bouwer, L. M., Winsemius, H. C., de Moel, H., and Ward, P. J.: FLOPROS: an evolving global database of flood protection standards, Nat. Hazards Earth Syst. Sci., 16, 1049-1061, https://doi.org/10.5194/nhess16-1049-2016, 2016.

Sivapalan, M., Savenjie, H. G., and Blöschl, G.: Socio-hydrology: A new science of people and water, Hydrol. Process., 26, 12701276, 2012.

Tobin, G. A.: The Levee Love Affair: A Stormy Relationship, Water Resour. Bull., 31, 359-367, 1995.

von Neumann, J. and Morgenstern, O.: Theory of Games and Economic Behavior (Third ed.), Princeton, NJ: Princeton University Press, 1953.
Vorogushyn, S., Bates, P. D., de Bruijn, K., Castellarin, A., Kreibich, H., Priest, S., Schröter, K., Bagli, S., Blöschl, G., Domeneghetti, A., Gouldby, B., Klijn, F., Lammersen, R., Neal, J. C., Ridder, N., Terink, W., Viavattene, C., Viglione, A., Zanardo, S., and Merz, B.: Evolutionary leap in large-scale flood risk assessment needed, Wiley Interdisciplinary Reviews: Water, 5, e1266, https://doi.org/10.1002/wat2.1266, 2018.

Ward, P. J., Jongman, B., Aerts, J. C. J. H., Bates, P. D., Botzen, W. J., Loaiza, A. D., Hallegatte, S., Kind, J. M., Kwadijk, J. C. J., Scussolini, P., and Winsemius, H. C.: A global framework for future costs and benefits of river-flood protection in urban areas, Nature climate change, 7, 642-646, 2017.

Wenger, C: Better use and management of levees: Reducing flood risk in a changing climate, Environ. Rev., 23, 240-255, 2015.

Werner, B. and McNamara, D.: Dynamics of coupled human-landscape systems, Geomorphology, 91, 393-407, https://doi.org/10.1016/j.geomorph.2007.04.020, 2007.

White, G. F.: Human adjustment to floods, Chicago, University of Chicago Press, 1945.

White, G. F.: A Perspective on Reducing Losses from Natural Hazards, B. Am. Meteorol. Soc., 75, 1237-1240, 1994. 